Published in: Fütterer, D K, Damaske, D, Kleinschmidt, G, Miller, H\& Tessensohn, F (eds.), Antarctica: contributions to global earth sciences, Springer, Berlin, Heidelberg, New York, 45-54

http://dx.doi.org/10.1007/3-540-32934-X

The original publication is available at http://www.springerlink.com see

http://dx.doi.org/10.1007/3-540-32934-X 25

Data are available at: http://dx.doi.org/10.1594/PANGAEA.605207

\title{
Style of Uplift of Paleozoic Terranes in Northern Victoria Land, Antarctica: Evidence from K-Ar Age Patterns
}

\author{
Christopher J. Adams \\ Institute of Geological and Nuclear Sciences, PO Box 30368, Lower Hutt, New Zealand, <argon@gns.cri.nz>
}

\begin{abstract}
K-Ar ages of 82 slate and schist (white-mica-rich wholerock) samples are reported for Late PrecambrianEarly Ordovician metamorphic rocks of the Wilson, Bowers and Robertson Bay terranes of northern Victoria Land. These are amalgamated in two vertical sections along composite NE-SW horizontal profiles across (1) Oates Coast in the north, and (2) Terra Nova Bay area in the south. The ages are in the range 328-517 Ma. Both profiles show some age variation with altitude, but more importantly, they define an invertedwedge shaped pattern, reflecting a "pop-up" structure. This is oriented NW-SE at the eastern margin of the Wilson terrane, and the edges coincide with the Exiles and Wilson Thrusts which cross the region. Ages inside the "pop-up" structure are younger, ca. 460-480 $\mathrm{Ma}$, than those along its eastern and western flanks,ca. 490-520 Ma.TheK-Arage patterns thus demonstrate a late Ross Orogenic age (ca. $460 \mathrm{Ma}$ ) for this structure, which may be associated with assembly of the Wilson and Bowers terranes.
\end{abstract}

\section{Introduction}

The Cambrian-Ordovician Ross Orogen forms the axis of the Transantarctic Mountains along the eastern edge of the Antarctic craton (Fig. 4.6-1, inset). At the Ross Sea and Pacific Ocean margins in northernVictoria Land (NVL), it comprises three terranes (Fig. 4.6-1, inset A): (1) a broad, western Wilson Terrane of greenschist facies metasediments (Berg Group,Priestley Formation and Priestley Schist), greenschist to amphibolite facies orthogneiss (Wilson Gneiss) and paragneiss, (Rennick Schist), and Late Cambrian-Ordovician granitoid complexes (Granite Harbour Intrusives), (2) a narrow, central Bowers Terrane of volcanics (Glasgow Volcanics) and low-grade greenschist facies, Cambrian, metasediments (Sledgers and Mariner Groups) and (3) a broad, eastern Robertson Bay Terrane, of greenschist facies, Early Ordovician, turbiditic metasediments (Robertson Bay Group and Millen Schist) (for comprehensive references see Tessensohn et al. 1981). Wilson, Bowers and Robertson Bay terrane rocks are intruded by Devonian-Early Carboniferous Admiralty Intrusives and there are probable scattered, volcanic correlatives (e.g., Gallipoli Volcanics) in all terranes. Major regional metamorphism associated with the Ross Orogeny, occurred in the three terranes in Late Cambrian to Early Ordovician times, now recorded, in part, as regional K-Ar cooling age patterns, 505-455 Ma (Adams et al. 1982; Adams and Kreuzer 1984). However, the terranes are separated by the major Lanterman and Leap Year Faults, between (and close to) which occur anomalously younger ( $<375 \mathrm{Ma}$ ) age patterns, possibly attributable, in part, to terrane assembly (Adams and Kreuzer 1984). In the eastern part of the Wilson Terrane, an eastdipping Exile Thrust, and a west-dipping Wilson Thrust, form a major, inverted wedge-shaped, (or"pop-up") structure of the Ross Orogeny (Flöttman and Kleinschmidt 1991). Field investigations during German and Italian expeditions of 1989 and 1991 enabled broad rock sampling in profiles along the Oates Coast, Northern Victoria Land, and at Terra Nova Bay, Ross Sea. K- 
Ar mineral and total rock ages are used here to test the Flöttman and Kleinschmidt (1991) uplift model and, combining with existing K-Ar age data (Adams 1997; Adams and Kreuzer 1984; Borsi et al. 1989; Kreuzer et al. 1987; Tonarini and Rocchi 1994; Vita et al. 1991; Vita-Scaillet 1994), establish a regional Paleozoic uplift history.

K-Ar analytical techniques are given in Adams and Graham (1986). Age errors are given at 95\% confidence limits, and are based upon combined percentage reproducibilities of repeated $\mathrm{K}$ and $\mathrm{Ar}$ analyses of standard slate samples. Sample data are listed in Table 4.6-1, and age data are shown in maps and vertical profiles in Fig. 4.6-1 (Oates Coast sector) and Fig. 4.6-2 (Terra Nova Bay sector).

\section{Age Patterns in the Oates Coast Sector}

Along the Oates Coast, the K-Ar dating samples (35 from Table 4.6-1 this study, and 6 from comparable data from Adams 1997) lie within coastal sections straddling the lower Matusevich and Rennick Glaciers (Fig. 4.6-1), and the sampling area crosses important regional terrane structures. To accommodate horizontal and vertical variation within each terrane, the age data are projected normally on to two vertical, ENE-WSW, profiles (A-A' and B-B' in Fig. 4.6-1), and joined to form a composite profile (lower section, Fig. 4.6-1), viewed from the Pacific Ocean, looking inland towards the SSE, as indicated by the open arrows. The majority of the ages, 460-513 Ma, are compa-younger ages decreasing with altitude (Adams and rable with those of the main 460-524 Ma trend of the Adams Kreuzer 1984). These main, 460-505 Ma, ages are similar and Kreuzer (1984) profile across central NVL (reproduced to those of Granite Harbour Intrusives at Terra Nova Bay in Fig. 4.6-3). A minority group of samples, 320-445 Ma, all (Borsi et al. 1989; Vita et al. 1991) which reflect the last from within the Bowers Terrane, show the pattern of regional, thermal (or more strictly speaking, cooling) event within the Ross Orogen. This thermal effect of Granite Harbour Intrusives is pervasive throughout the Wilson Terrane, and commonly obliterates age evidence for earlier metamorphism. In this respect, the vertical age profile (Fig. 4.6-1) thus reveals an important pattern of K-Ar data in the Wilson Terrane, namely, age groups of low-medium grade metasediment samples at its eastern extremity, 486-513 Ma (Kavrayskiy Hills), and westernmost extremity, 483-506 Ma (Berg Mountains), are older than those of the central portion (Pomerantz Tableland, Daniels Range), 463-484 Ma, entirely from high-grade gneisses and granitoids. These age groups are nicely constrained by the westward-dipping Wilson Thrust in the east, and the eastwarddipping Exiles (but possibly also Lazarev) Thrust in the west (Fig. 4.6-1). The age pattern thus supports the Flöttman and Kleinschmidt (1991) "pop-up" mechanism, with the vertical displacement of a late-Ross cooling age pattern derived from Granite Harbour Intrusives at the Wilson Terrane core (Fig. 4.6-4, shaded area), to the level of early-Ross cooling age patterns derived from metamorphism at higher structural levels, and now preserved only at the structure flanks.

\section{Age Patterns in the Terra Nova Bay Sector}

K-Ar ages of samples from the Terra Nova Bay sector (47 from Table 4.6-1 of this study, and augmented with 18 comparable ages from Adams and Kreuzer 1984), fall mainly within two areas which straddle the Mariner and Priestley Glaciers (Fig. 4.6-2), and again the dating sampling area crosses important regional terrane structures. As for Fig. 4.6-1, the age data are projected on to two vertical ENE-WSW profiles (A$A^{\prime}$ and $B-B^{\prime}$ in Fig. 4.6-2), and then superimposed to form a composite profile (lower section, Fig. 4.6-2), but in this case viewed from the Ross Sea looking inland towards the NNW, as indicated by the open arrows. In the Wilson Terrane part, the major age group is again 467-495 Ma, whilst a smaller group in the Bowers Terrane, 328-448 Ma (Table 4.6-1), follows the established pattern of ages decreasing (to 310 Ma) with altitude (Adams and Kreuzer 1984). At the western end of the profile, along the western side of the Priestley Glacier, there is again a significant group of older ages, 494-557 Ma, from lower-grade, Priestley Formation metasediments.At these localities Rb-Sr whole-rock isochron ages are $510 \pm 6$ to 570 $\pm 9 \mathrm{Ma}$ (Adams 1997). Clearly both K-Ar and Rb-Sr data sets data reflect earlier events than those recorded by K-Ar cooling age patterns (454-495 Ma) in the extensive Granite Harbour Intrusive complexes to the east, between the Priestley and Aviator Glaciers (Borsi et al. 1989; Vita et al. 1991), and to the north in central NVL (Kreuzer et al. 1987). The early regional metamorphism both here, and in the 
Oates Coast sector (above), is thus probably Late Neoproterozoic, and certainly predates Bowers and Mariner Group (Cambrian) sedimentation. The division of the cooling age patterns coincides with a major eastdipping fault along the Priestley Glacier (Flöttman and Kleinschmidt 1991). However, from the available age data (this work, and Vita-Scaillet et al. 1994), there appears to be no corresponding older ( $>500 \mathrm{Ma}$ ) age group at the eastern flank of the Wilson Terrane, similar to that in the Oates Coast profile east of the Wilson Thrust, e.g., at Kavrayskiy Hills.

\section{Age Patterns in Bowers and Robertson Bay Terranes}

$\mathrm{K}-\mathrm{Ar}$ and ${ }^{40} \mathrm{Ar} /{ }^{39} \mathrm{Ar}$ ages (Adams and Kreuzer 1984; and this work Table 4.6-1,Wright and Dallmeyer 1991; Capponi et al. 2002) in Robertson Bay Group slates (and possibly related Millen Schist) at the Bowers/ Robertson Bay terrane boundary mostly conform to the broad, 470-490 Ma trend continuing to the east (Fig. 4.6-3). Since Robertson Bay Group includes Tremadocian (490-495 Ma) fossil localities at Handler Ridge (Burrett and Findlay 1984), albeit in unusual limestone enclaves, these ages can be simply interpreted as a cooling pattern following late Early Ordovician metamorphism. However, there are significant exceptions older than this, from $505 \pm 10$ to $525 \pm 11 \mathrm{Ma}$, especially immediately west of the Leap Year Fault, possibly the result of incomplete argon degassing during metamorphism or incorporation of excess argon in surviving mineral phases (Wright and Dallmeyer 1991). However, sequences here are tectonically complex and uncertain, so a pre-Ordovician stratigraphic break and older metamorphism remain an alternative possibility. Capponi et al. (2002) report $\mathrm{Rb}-\mathrm{Sr}$ isochron and ${ }^{40} \mathrm{Ar} /{ }^{39} \mathrm{Ar}$ actinolite age data for meta-igneous rocks in the northern Robertson Bay terrane and ca. $10 \mathrm{~km}$ from the Bowers/ Robertson Bay terrane boundary. Their $361 \pm 70 \mathrm{Ma} \mathrm{Rb-Sr}$ age is an errorchron, and its large error does not allow a discrimination of a Ross Orogenic plutonic, or post-Ross Orogenic metamorphic, event. Similarly, the actinolite ${ }^{40} \mathrm{Ar}{ }^{39} \mathrm{Ar}$ release pattern has no clear plateau, but shows an increasing age pattern, 345-395 Ma, from low to high temperature, and a secure interpretation is not possible.

\section{Uplift History of the Terranes}

The Exiles and Wilson Thrusts define an uplift structure in the Wilson Terrane, which displaces established late-Ross K-Ar cooling age patterns. Since, with one exception (see below), this structure includes ages as young as $462 \mathrm{Ma}$, then the "pop-up" structure should be younger than this, but still a late-Ross tectonic feature (Kleinschmidt and Tessensohn 1987; Flöttman and Kleinschmidt 1991). However, a single, anomalous, young age, $412 \pm 8 \mathrm{Ma}$, from sheared granite near (but above) the Exiles Thrust, might indicate uplift as young as mid-Devonian, possibly a younger tectonic event more related to that seen in the adjacent Bowers Terrane. However, the marked decrease in K-Ar ages in the latter, to ca. $300 \mathrm{Ma}$ (Adams and Kreuzer 1984), both with depth (i.e. present-day altitude) and proximity to the Rennick Fault (Fig. 4.6-3), reflects a more localised thermal event at the Wilson/Bowers Terrane boundary, at least in part, younger than ca. $300 \mathrm{Ma}$. Significantly, the zone of oldest (>500 Ma) K-Ar ages, along the eastern Wilson Terrane margin, intervenes between this young (strike-slip?) fault zone, and the young "pop-up" structure of the Wilson/Exiles Thrusts, suggesting that the two features are probably unconnected.

Capponi et al. (1999) demonstrated a sinistral strikeshearing event in Lanterman Range metamorphic rocks close to the Bowers/Wilson terrane boundary (but not confined solely to that boundary fault) and disturbed ${ }^{40} \mathrm{Ar}{ }^{39} \mathrm{Ar}$ age patterns from rocks close to the Lanterman Fault (Capponi et al. 2003) were interpreted by them as probably reflecting a late-Ross thermal event. However, Adams and Kreuzer (1984, Table 2) reported a K-Ar age, $420 \pm 17 \mathrm{Ma}$ for actinolite on late shear planes in the Lanterman Complex. Capponi et al. (2002) preferred a probable Late Devonian-Early Carboniferous age for an event in the Barber Glacier, northern Robertson Bay terrane, but their dating samples were not taken close to the terrane boundaries themselves, whilst those sample locations of Adams and Kreuzer (1984), Wright and Dallmeyer (1991), and Adams (this work) include many close to $(<3 \mathrm{~km})$ terrane boundaries. Also, dated samples of these earlier studies were mostly white micas, which are more likely than amphiboles to 
record subtle low-temperature, late metamorphic events at the terrane boundary faults. Clearly there is a need for more detailed dating on specific fault fabrics within both zones.

\section{Acknowledgments}

I thank Norbert Roland and Carlo Alberto Ricci for invitations to participate in German/Italian Antarctic research activities 1989-1991. Many colleagues on those expeditions are thanked for their ready advice and assistance. The writer also gratefully acknowledges financial support from Alexander von Humboldt Foundation (Germany), and Transantarctic Expedition Association (New Zealand and United Kingdom) to attend ISAES IX in Potsdam and undertake further related studies in Germany. Giovanni Capponi and Peter Horn are thanked for their careful reviews.

\section{References}

Adams CJ (1987) Geochronological evolution of the western margin of Northern Victoria Land: Rb-Sr and K-Ar dating of the Berg Group and Berg/Archangel Granites. In: Roland N (ed) German Antarctic North Victoria Land Expedition 1990/91 GANOVEX V, 2. Geol Jb B89:179-104

Adams CJ (1997) Initial strontium isotopic signatures of Late Precambrian-Early Paleozoic metasediments from northern Victoria Land, East Antarctica. In: Ricci C-A (ed) The Antarctic region: geological evolution and processes, Terra Antartica Publication, Siena, pp 227-231

Adams CJ, Graham IJ (1986) Metamorphic and tectonic geochronology of the Torlesse Terrane, Wellington, New Zealand. New Zealand J Geol Geophys 39:157-180

Adams CJ, Kreuzer H (1984) potassium-argon age studies of slates and phyllites from the Bowers and Robertson Bay Terranes, North Victoria Land, Antarctica. In: Roland N (ed) German Antarctic North Victoria Land Expedition 1982/83 GANOVEX III. Geol Jb B60:265-288

Adams CJ, Wodzicki A, Laird MG, Bradshaw JD (1982) Potassiumargon geochronology of the Precambrian-Cambrian Wilson and Robertson Bay Groups and Bowers Supergroup, Northern Victoria Land, Antarctica. In: Craddock C (ed) Antarctic geoscience, Madison, Wisconsin, pp 543-548

Borsi L, Ferrara G, Tonarini S (1989) Geochronological data on Granite Harbour Intrusives from Terra Nova Bay and Priestley Glacier, Victoria Land,Antarctica.Proceedings of the meeting "Earth Science investigations in Antarctica", Siena, 2-3 September 1987. Memoria Societa Italiana 33:161-169

Burrett CF, Findlay RH (1984) Cambrian and Ordovician conodonts from the Robertson Bay Group,Antarctica, and their tectonic significance. Nature 307:723-725

Capponi G, Crispini L, Meccheri M (1999) Structural history and tectonic evolution of the boundary between the Wilson and Bowers terranes, Lanterman Range, northern Victoria Land, Antarctica. Tectonophysics 312:249-266

Capponi G, Castorina F, Di Pisa A, Meccheri M, Petrini R, Villa IM (2002) The metaligeneous rocks of the Barber Glacier area (northern Victoria Land): a clue to the enigmatic Borchgrevink orogeny? In: Gamble J, Skinner D, Henrys S (eds) Antarctica at the close of a millennium, Royal Soc New Zealand Bull 35:99-104

Capponi G, Crispini G, Di Vincenzo G, Palmeri R (2003) Microtextural and petrological insight into shear zones from the Lanterman Range (NVL, Antarctica): contrasting metamorphic evolution at the contact between terranes. Terra Antartica Reports 9:159-162 Flöttman T, Kleinschmidt G (1991) Opposite thrust systems in Northern Victoria Land, Antarctica: Imprints of Gondwana's Paleozoic accretion. Geology 19:45-47

Kleinschmidt G, Tessensohn F (1987) Early Paleozoic westward directed subduction at the Pacific margin of Antarctica. In: McKenzie G (ed) Gondwana Six: structure, tectonics, and geophysics. Geophys Monograph Series 40:89-105

Kreuzer H,Höhndorf A, Lenz H, Müller P,Vetter U (1987) Radiometric ages of Pre-Mesozoic rocks from Northern Victoria Land, Antarctica. In: McKenzie GD (ed) Gondwana Six: structure, tectonics and geophysics, Geophys Monograph Series 40:31-48

Tessensohn F, Duphorn K, Jordan H, Kleinschmidt G, Skinner DNB, Vetter U, Wright TO, Wyborn D (1981) Geological comparison of basement units in North Victoria Land,Antarctica. In: GANOVEX German Antarctic North Victoria Land Expedition 1979/80. Geol $\mathrm{Jb}$ B41:31-88

Tonarini S, Rocchi S (1994) Geochronology of Cambro-Ordovician intrusives in NorthernVictoria Land: a review. Terra Antartica $1: 59-62$

Vita G, Lombardo B, Guiliani O (1991) Ordovician uplift pattern in the Wilson Terrane of the Borchgrevink Coast, Victoria Land, Antarctica. Proceedings of the meeting "Earth Science investigations in Antarctica", Siena, 4-6 October 1989. Memoria Societa Italiana 46:257-265

Vita-Scaillet G, Feraud G, Ruffet G, Lombardo B (1994) K/Ar and ${ }^{40} \mathrm{Ar} /{ }^{39} \mathrm{Ar}$ laser-probe ages of metamorphic micas and amphibole of the Wilson Terrane and Dessent Unit, Northern Victoria Land (Antarctica): their bearing on the regional post-metamorphic cooling history. Terra Antartica 1:59-62

Wright TO, Dallmeyer, RD (1991) The age of cleavage development in the Ross orogen, northernVictoria Land,Antarctica: evidence from ${ }^{40} \mathrm{Ar} r^{39} \mathrm{Ar}$ whole-rock slate ages. J Structural Geol 13:677-690 

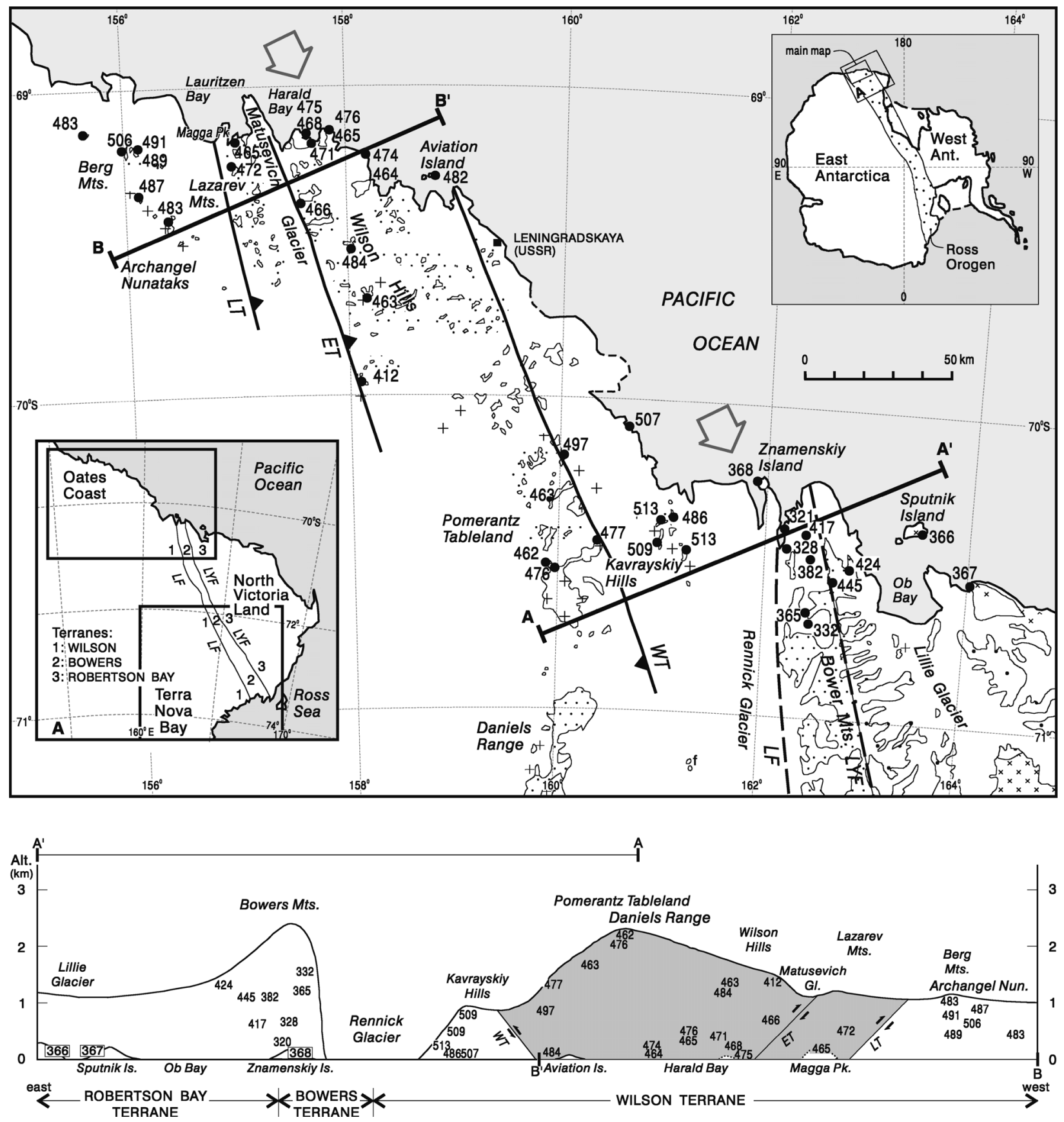

Fig. 4.6-1. Geological map of Oates Coast, and hinterland of the Matusevich and Rennick Glaciers, and $\mathrm{K}$-Ar sample locations. Rock type ornament is as shown in the legend of Fig. 4.6-2. Antarctic inset diagram at top right indicates study area with respect to Ross Orogen. Inset $A$ at bottom left indicates main tectonostratigraphic terranes of northern Victoria Land, with respect to the two study areas. The terranes are bounded by the Lanterman (LF) and Leap Year (LYF) faults. The lines $A-A^{\prime}$ and $B-B^{\prime}$ indicate position of vertical profiles used to create the composite K-Ar age profile in the lower part of diagram, and the open arrows indicate the viewpoint aspect of this. Age data on the vertical profile are in millions of years (Ma), those in boxes are Admiralty Intrusives. Grey shaded area indicates the suggested "pop-up" structure of Flöttman and Kleinschmidt (1991) with its boundary faults (marked on the map) as the Exiles $(E T)$ and Wilson (WT) Thrusts. $L T$ is the Lazarev thrust 


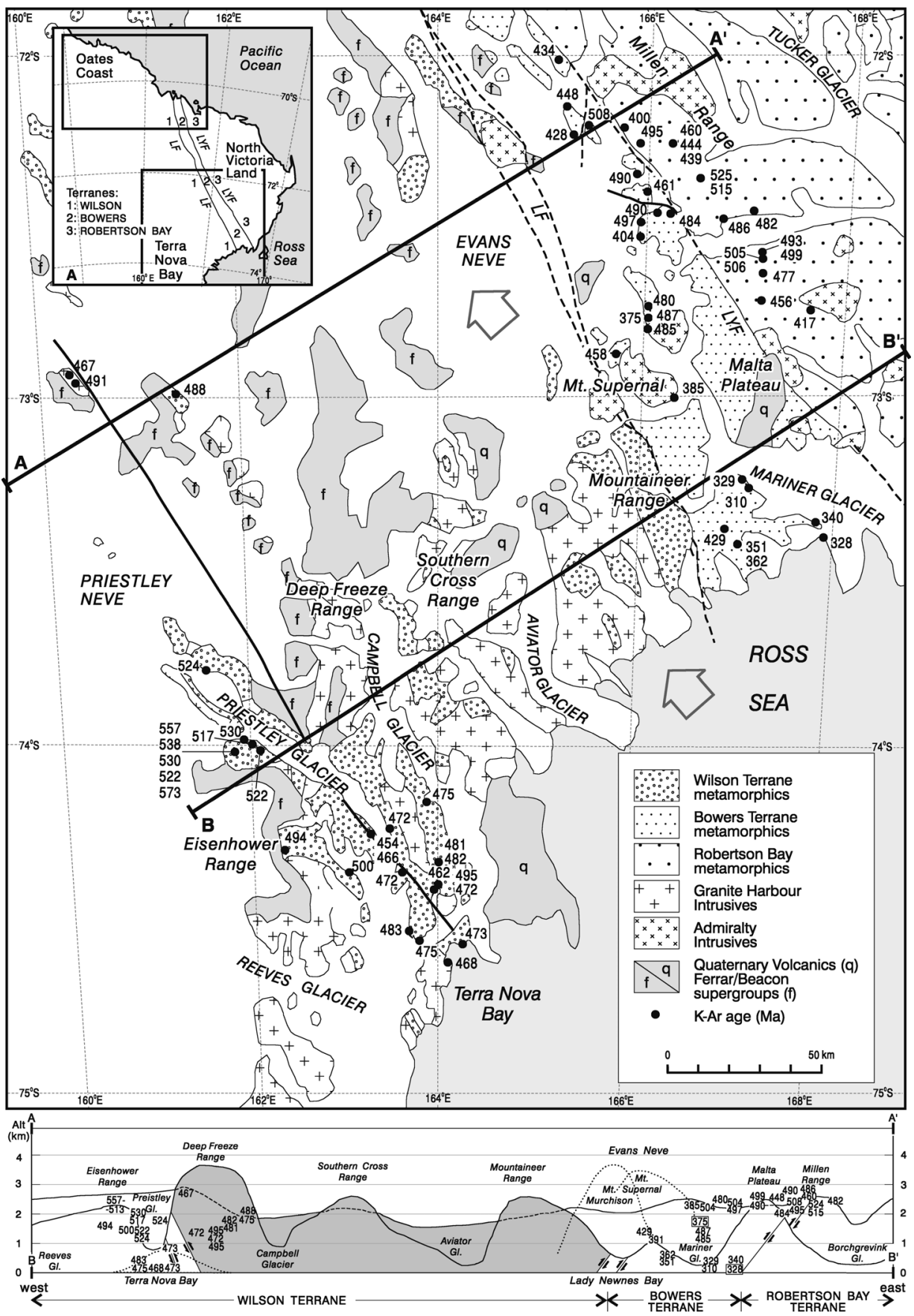

Fig. 4.6-2. Geological map of Terra Nova Bay area, and hinterland of the Priestley and Mariner Glaciers, and K-Ar sample locations. Inset $A$ : the principal terranes of northern Victoria Land designated as in Fig. 4.6-1, the terranes are bounded by the Lanterman (LF) and Leap Year ( $L Y F)$ faults. The lines $A-A^{\prime}$ and $B-$ $B^{\prime}$ indicate position of vertical profiles used to create the composite K-Ar age profile in the lower part of diagram, and the open arrows indicate the viewpoint aspect of this. Age data on the vertical profile are in millions of years (Ma), those in boxes are Admiralty Intrusives. Grey shaded area indicates the suggested "pop-up" structure of Flöttman and Kleinschmidt (1991) 


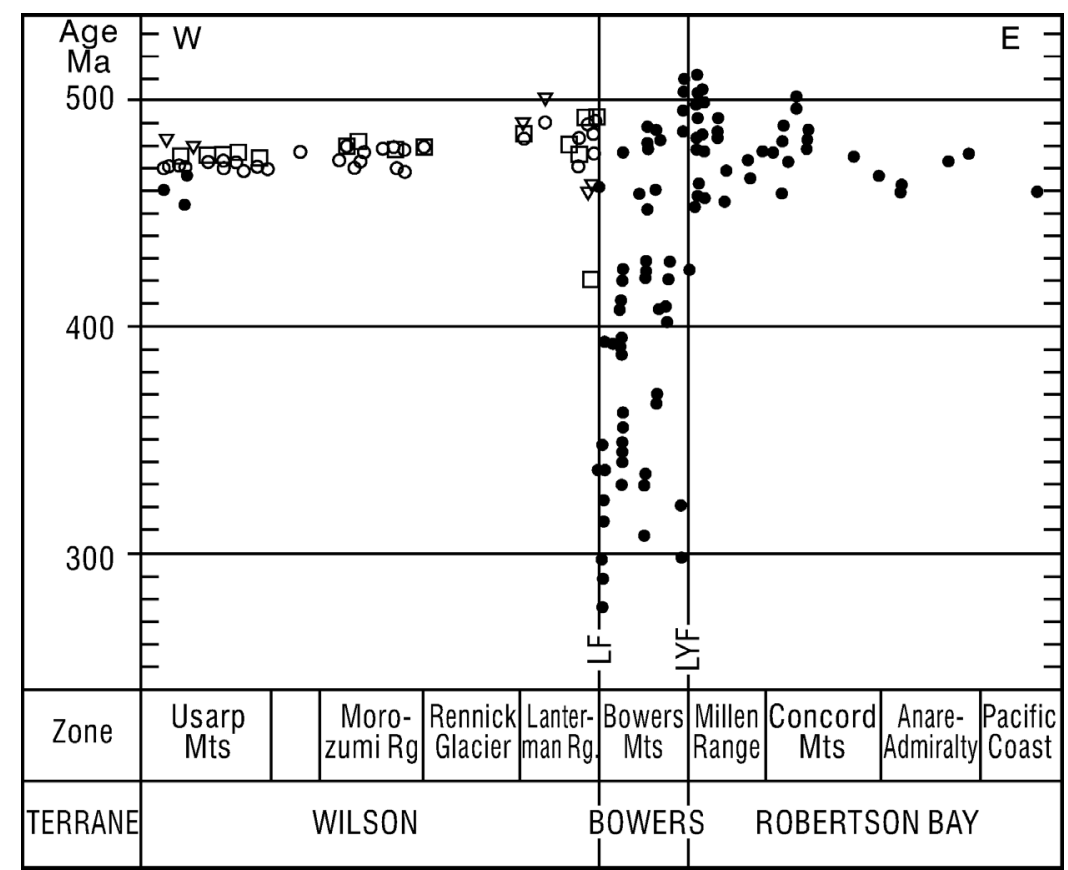

Fig. 4.6-3. Variation of K-Ar ages in North Victoria Land, in relation to Wilson, Bowers and Robertson Bay Terranes (redrawn from data of Adams and Kreuzer 1984). Solid dots refer to K-Ar whole-rock ages, all are fine white-mica slates, open symbols, various K-Ar mineral (mostly mica) ages. LF and LYF refer to Lanterman and Leap Year Faults respectively

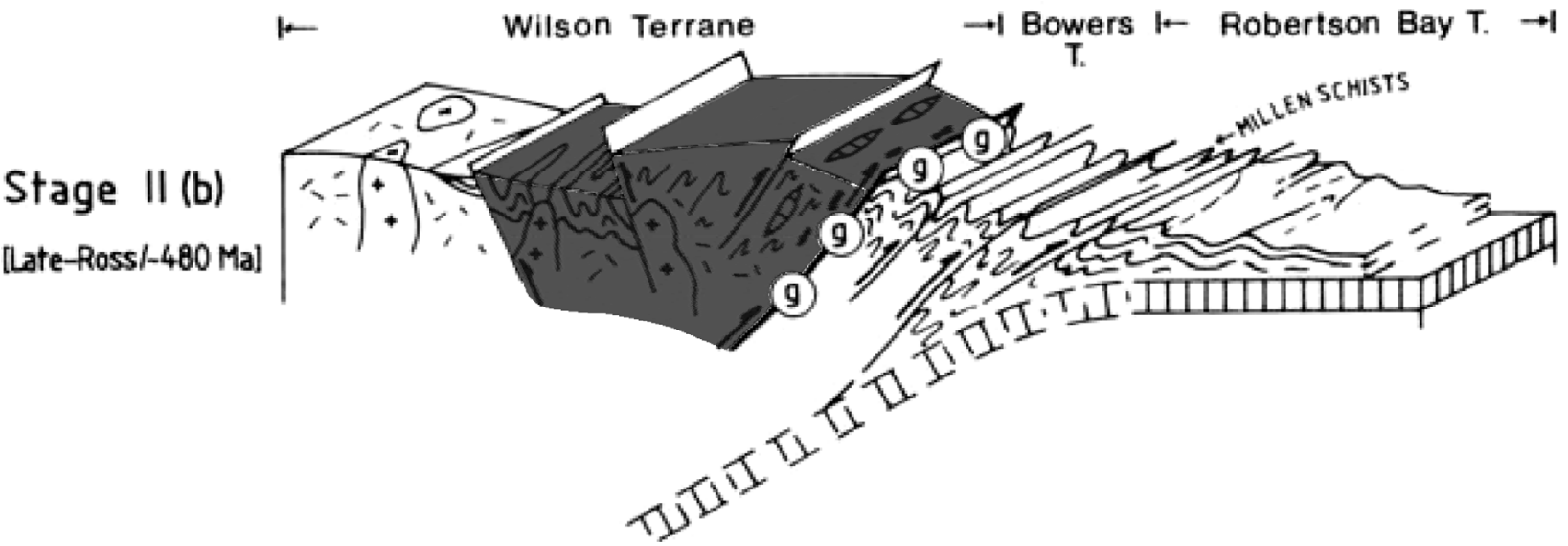

Fig. 4.6-4. The Stage II(b) - Late Ross Orogeny, ca. $480 \mathrm{Ma}$, in North Victoria Land, Antarctica, of Kleinschmidt and Tessensohn (1987), showing the "pop-up" structure (shaded area) defined by Flöttman and Kleinschmidt (1991)

Table 4.6-1. K-Ar ages from Oates Coast sector (Pacific margin) and Terra Nova Bay sector (Ross Sea) see doi:10.1594/PANGAEA.605207 